\title{
Methods for the diagnosis of bacterial fish diseases
}

\author{
Brian Austin ${ }^{1}$
}

Received: 26 March 2019 / Accepted: 24 June 2019 / Published online: 11 November 2019

(c) Ocean University of China 2019

\begin{abstract}
The diagnosis of bacterial fish diseases has progressed from traditional culture-dependent methods involving the recovery of pathogens on agar-containing media and identification by examination of phenotypic traits. Newer approaches centre on culture-independent approaches. A problem with culturing is that it lacks sensitivity, tends to be slow, and its success depends on the composition of the media and incubation conditions employed. In contrast, culture-independent methods, now centring on molecular methods, are highly specific and sensitive. This raises an important issue that detection of very low numbers of bacterial cells does not necessarily imply the presence of clinical disease. Positivity could reflect background populations of the pathogen that may be present in the aquatic environment.
\end{abstract}

Keywords Culturing $\cdot$ Phenotyping $\cdot$ Serology $\cdot$ Molecular methods $\cdot$ Rapid techniques

\section{Introduction}

A diverse range of Gram-positive and Gram-negative bacteria have been associated with diseases of marine fish, worldwide (Table 1). Overall, greater attention has been focused on aquaculture rather than wild stocks. The pathogens have been associated with a wide range of clinical manifestations including ulcerations, swellings, erosions and haemorrhagic septicaemias. The diagnostic procedures have been summarised in Table 2 and Fig. 1. Unlike other veterinary and medical counterparts, diagnosis centres on the identification of the pathogen rather than the immediate control of the disease (Austin and Austin 2016). Inevitably, this process takes longer than, for example, a trip to the human physician. Here, diagnosis may result initially from consideration of the gross clinical signs on the patient leading to the rapid implementation of a treatment regime. Certainly, fish disease diagnosis has undergone a transformation. Since the end of the twentieth century, there has been a move away from the traditional histology and culture-dependent approaches. The latter involved the acquisition of cultures and their

\section{Edited by Xin $\mathrm{Yu}$.}

Brian Austin

baustin5851@gmail.com

1 Institute of Aquaculture, University of Stirling, Stirling FK9 4LA, Scotland, UK time-consuming identification. Subsequently, attention has been focused on culture-independent techniques, notably those embracing developments in molecular biology. A topical example is sequencing of the 16S rRNA gene, which does not need intact, viable bacterial cells. The advantage to these culture-independent approaches is speed and accuracy; the bacteria may be studied and identified regardless of whether or not they may be grown in the laboratory. Moreover, there is a very high level of specificity, and this is important when diagnosing disease (Austin 2017).

\section{Culture-dependent techniques}

A traditional approach to bacterial fish disease diagnosis centred on attempts to culture the pathogen from pathological material followed by identification using phenotypic data with comparison to published diagnostic schemes, such as those in "Bergey's Manual of Systematic Bacteriology". Where diseased tissues are exposed to the surrounding environment, such as with surface ulcers and/or gills, there is an inherent risk of contamination and difficulties in discerning the relevance of resulting bacterial growth, i.e., which is the pathogen, a secondary invader of already dead or diseased tissue, or a chance contaminant (Fig. 2)? Internal tissues are less likely to be plagued by contaminants providing that they have been derived from freshly dead or moribund fish rather than specimens that have been deceased for numerous hours (Austin and Austin 2016). Personal experience is that the 
Table 1 Dominant bacterial pathogens of marine fish (based on Austin and Austin 2016)

\begin{tabular}{|c|c|c|}
\hline Pathogen & Disease & Geographical distribution \\
\hline \multicolumn{3}{|l|}{ Gram-positive bacteria } \\
\hline Mycobacterium spp. & Mycobacteriosis (fish tuberculosis) & Worldwide \\
\hline Nocardia spp. & Nocardiosis & Worldwide \\
\hline Renibacterium salmoninarum & Bacterial kidney disease & Europe, Japan, North and South America \\
\hline Streptococcus iniae & Streptococcosis & widespread \\
\hline Streptococcus parauberis & Streptococcosis & Europe, USA \\
\hline \multicolumn{3}{|l|}{ Gram-negative bacteria } \\
\hline Aeromonas salmonicida & Ulcer disease & Baltic Sea, North Sea \\
\hline Aliivibrio salmonicida & Cold-water vibriosis, Hitra disease & Canada, Norway, Scotland \\
\hline Aliivibrio wodanis & Winter ulcer disease/syndrome & Iceland, Norway, Scotland \\
\hline Francisella noatunensis & Francisellosis & Japan, South America, UK, USA \\
\hline Moritella marina & Skin lesions & Iceland \\
\hline Moritella viscosa & Winter ulcer disease/syndrome & Iceland, Norway, Scotland \\
\hline Photobacterium damselae subsp. damselae & Photobacteriosis & Asia, Europe, USA \\
\hline Photobacterium damselae subsp. piscicida & Pasteurellosis, pseudotuberculosis & Europe, Japan, USA \\
\hline Piscirickettsia salmonis & $\begin{array}{l}\text { Coho salmon syndrome, salmonid rickettsial } \\
\text { septicaemia }\end{array}$ & Canada, Chile, Greece, Norway, Scotland, USA \\
\hline Shewanella putrefaciens & Septicaemia & Saudi Arabia \\
\hline Tenacibaculum dicentrarchi & - & Spain \\
\hline Tenacibaculum discolor & - & Spain \\
\hline Tenacibaculum gallaicum & - & Spain \\
\hline Tenacibaculum maritimum & $\begin{array}{l}\text { Bacterial stomatitis, gill disease, black patch } \\
\text { necrosis }\end{array}$ & Europe, Japan, North America \\
\hline Tenacibaculum soleae & Tenacibaculosis & Spain \\
\hline Vibrio aestuarianus & - & China \\
\hline V. alginolyticus & Eye disease, septicaemia & Asia, Europe, Israel \\
\hline V. anguillarum & Vibriosis & worldwide \\
\hline V. harveyi & $\begin{array}{l}\text { Eye disease, necrotising enteritis, vasculitis, } \\
\text { granuloma }\end{array}$ & Europe, Japan, Taiwan, USA \\
\hline V. ichthyoenteri & Intestinal necrosis/enteritis & Japan, Korea, USA \\
\hline V. mimicus & Ascites disease & China \\
\hline V. ordalii & Vibriosis & Worldwide \\
\hline V. parahaemolyticus & - & China, India \\
\hline$V \cdot$ ponticus & Ulcerative disease & China \\
\hline V. scophthalmi & - & Korea \\
\hline V. splendidus & Septicaemia, vibriosis & Norway, Spain \\
\hline V. vulnificus & Septicaemia & Europe, Japan, China, USA \\
\hline
\end{tabular}

kidneys are an excellent repository for pathogens. Having acquired diseased tissue, a comparatively narrow range of media have been used for culturing (see Table 3). Generally, the media lack imagination in terms of the characteristics of the host and thus the likely nutritional needs of the pathogen, i.e., the nutrients likely to be available in situ to the pathogen. Zobell's marine 2216E agar and/or thiosulphate citrate bile salt agar [TCBS; if vibrios were suspected (Eissa et al. 2019)] are often used with incubation at $15-37^{\circ} \mathrm{C}$ for 1-7 days for diseased marine fish. Indeed, scrutiny of recent issues of journals dealing with fish diseases, such as Aquaculture, points to laboratories using very short incubation regimes, i.e. 24 h (e.g. Behera et al. 2018; Yang et al. 2018) at temperatures more appropriate for human bacteria, i.e. incubation at $37^{\circ} \mathrm{C}$ (e.g. Behera et al. 2018). The relevance of this approach to fish pathology is questionable insofar as the incubation temperature is inevitably well above the optimum for most fish and their bacterial pathogens; not all fish pathogens grow at $37^{\circ} \mathrm{C}$ and may need longer than $24 \mathrm{~h}$ to develop visible colonies. Thus, Aeromonas salmonicida, Aliivibrio wodanis, Francisella noatunensis, Moritella marina, Moritella viscosa, Mycobacterium chelonei subsp. piscarium, Nocardia salmonicida, Photobacterium damselae subsp. piscicida, Renibacterium salmoninarum, 
Table 2 Procedures involved in the diagnosis of bacterial fish diseases

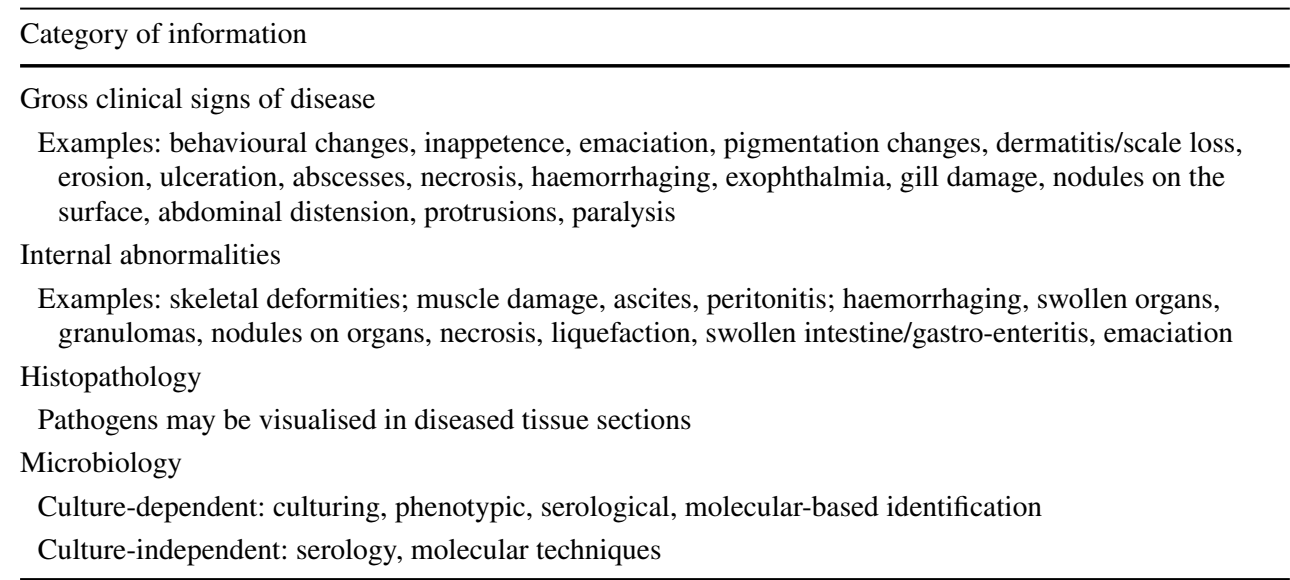

Fig. 1 Stages in the diagnosis of bacterial fish disease

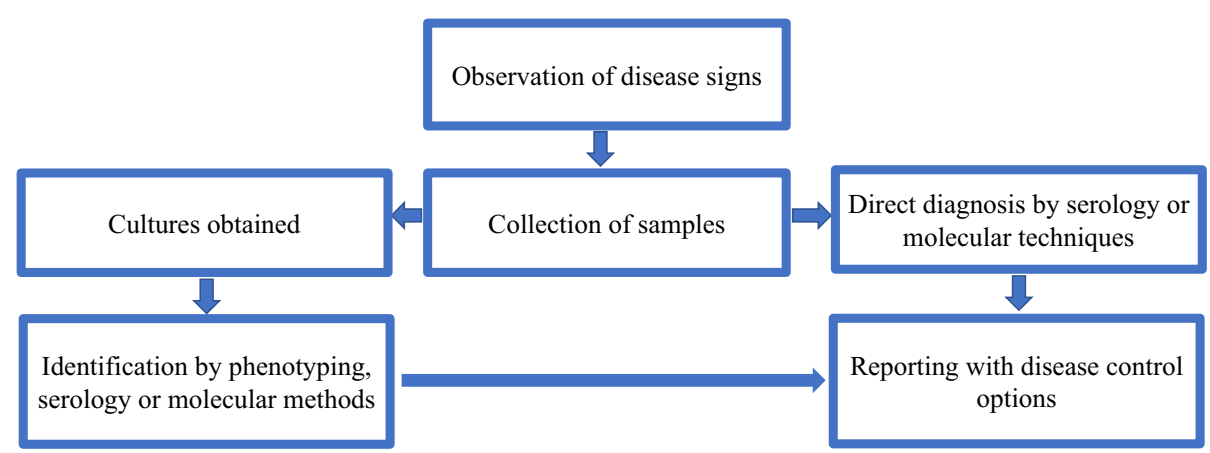

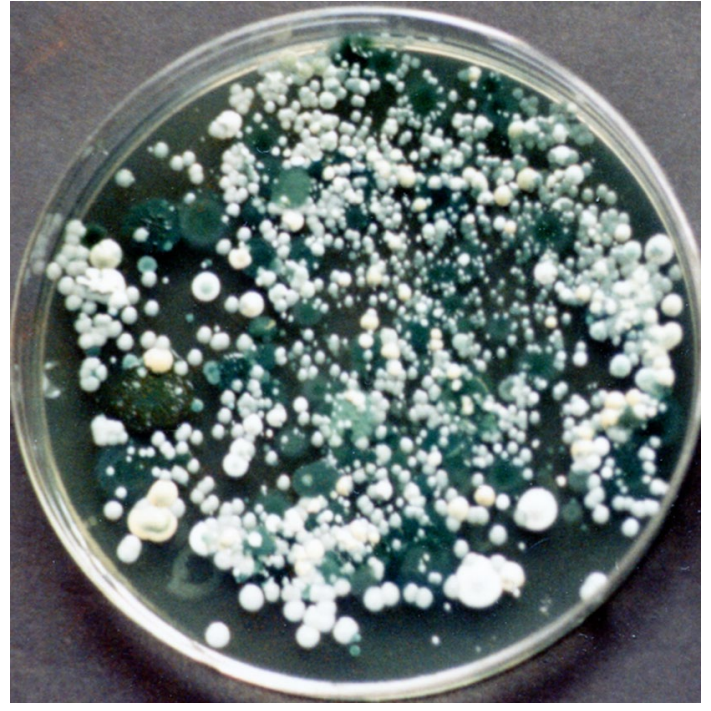

Fig. 2 The TCBS plate was inoculated with swabbed material from an ulcer on a marine flatfish. Following incubation at $25{ }^{\circ} \mathrm{C}$ for 7 days, a dense diverse array of bacterial colonies was observed. The issue for the microbiologist concerned the choice of colony to subculture for the development of one or more pure cultures for further study

Tenacibaculum maritimum and Vibrio tapetis do not grow at $37{ }^{\circ} \mathrm{C}$ (Austin and Austin 2016). Moreover, A. salmonicida, mycobacteria, nocardias and streptococci need longer than $24 \mathrm{~h}$ to develop colonies on solid media (Austin and Austin 2016). Some specialised media exist for the recovery of more fastidious pathogens, such as Mycobacterium and $R$. salmoninarum. In other cases, media may be supplemented with blood, e.g. 5-7.5\% (v/v) sheep or horse blood (Austin and Austin 2016). The desired outcome after incubation is the presence of dense bacterial growth; scant growth of colonies being indicative only of the presence of contaminants. Conventionally, pure dense growth from diseased tissues was considered to be indicative of the recovery of the actual pathogen. Yet, there is an awareness that some diseases may result from microbial consortia working together or sequentially, as will be discussed later. Nevertheless, the immediate goal has been the recovery of pure cultures, although the reasons for the choices of which colonies/growth to use from the isolation plates may well be highly subjective (Fig. 2). There is not any easy answer to this problem-does one take representatives of the dominant colony types? If so, how are the representative colonies chosen for purification. An alternative is to adopt a random approach by which the back of the inoculated agar plates is marked in numbered squares, and colonies removed for purification according to random number generators. In any case, the experience of the microbiologist is of paramount importance to ensure that meaningful colonies are chosen for further study. Then, 
Table 3 Examples of media used to recover marine bacterial fish pathogens

\begin{tabular}{|c|c|}
\hline Medium & Pathogen \\
\hline \multicolumn{2}{|l|}{ Non-selective medium } \\
\hline Brain heart infusion agar $+3 \%(w / v) \mathrm{NaCl}$ & Shewanella putrefaciens \\
\hline Cytophaga agar prepared in seawater & Tenacibaculum spp. \\
\hline Flexibacter maritimus medium (FMM) & Tenacibaculum spp. \\
\hline Marine 2216E agar & Photobacterium damselae, Vibrio spp. \\
\hline Tryptone soya agar $+1-2 \%(w / v) ~ N a C l$ & $\begin{array}{l}\text { Aeromonas salmonicida, Aliivibrio salmonicida, } V . \text { harveyi, } V . \text { splen- } \\
\text { didus, } V . \text { vulnificus }\end{array}$ \\
\hline \multicolumn{2}{|l|}{ Non-selective medium-enriched } \\
\hline AUSTRAL-Salmonid Rickettsial Septicaemia (SRS) broth + L-cysteine & Piscirickettsia salmonis \\
\hline Blood agar $+0.5-1.5 \%(w / v) \mathrm{NaCl}$ & $\begin{array}{l}\text { Aliivibrio wodanis, Moritella marina, Moritella viscosa, Photobacte- } \\
\text { rium damselae subsp. piscicida, V. splendidus, V. tapetis }\end{array}$ \\
\hline Cystine heart agar supplemented with $1 \%$ (w/v) haemoglobin & Francisella spp. \\
\hline Glucose asparagine agar & Nocardia spp. \\
\hline Kidney disease medium 2 (KDM2) & R. salmoninarum \\
\hline Löwenstein-Jensen medium/dorset egg medium & Mycobacterium spp., Nocardia spp. \\
\hline Middlebrook 7 H10 medium & Mycobacterium spp. \\
\hline Ogawa egg medium & Mycobacterium gordonae \\
\hline \multicolumn{2}{|l|}{ Selective medium } \\
\hline Coomassie brilliant blue agar & Aeromonas salmonicida \\
\hline Selective kidney disease médium (SKDM) & $R$. salmoninarum \\
\hline Thiosulphate citrate bile salt sucrose agar (TCBS) & Photobacterium damselae, Vibrio spp. \\
\hline
\end{tabular}

identification of the pure cultures may be achieved phenotypically, serologically or by molecular techniques (Austin and Austin 2016). The relevance of this approach to the host and its environment was rarely considered. Moreover, it has been unclear what proportion of bacterial cells actually produces colonies on solid media. It should be emphasised that the acquisition of one or more pure cultures does not necessarily mean that the actual pathogen has been recovered, but could reflect recovery of secondary invaders of already diseased tissue or even contaminants from the aquatic environment. Bacteriological examination on single occasions within a disease cycle would not identify possible microbial succession whereby an organism initiates an infection but subsequently become outcompeted by others. Yet, pure cultures do have their uses, serving for reference purposes, and enabling associated studies of epizootiology, pathogenicity factors and disease control (e.g. the determination of antibiotic sensitivity patterns).

From the conventional approach of using phenotypic traits together with diagnostic schemes, such as the tables contained in "Bergey's Manual of Systematic Bacteriology", many modern laboratories have subsequently adopted commercial systems, namely API 20E, API 20NE, API 50CH, API 50L, API-ZYM, Biolog-GN, Biolog-GP, Enterotubes and RapidID 32 systems, most of which were originally designed for use with medical bacteria. Therefore, their use for bacterial fish pathogens may well have led to erroneous identifications when comparisons of the test results were made with schemes designed for medical bacteria that grow well overnight at $37^{\circ} \mathrm{C}$. Nevertheless, it has been reported that results with Biolog-GP have been comparable with $16 \mathrm{~S}$ rRNA gene sequencing for some Gram-positive bacterial fish pathogens, correctly identifying 18 Lactococcus garvieae and 10 Streptococcus iniae cultures. Unfortunately, S. parauberis was misidentified as Enterococcus faecalis; the type strain of L. piscium did not grow on the recommended medium (Verner-Jeffreys et al. 2011). The alternative has been to use serology or molecular identification procedures with the cultures. This has enabled more accurate identifications, and, in the case of serology, quick results.

Certainly, there are many issues with culturing methods, and it is apparent that for the majority of known bacterial fish pathogens to grow in the laboratory a diverse range of media and incubation conditions are necessary. This means that laboratories need to encompass a wide range of approaches to ensure the best chance of recovering the pathogens in culture. Moreover, there is a major concern with the time needed to obtain and identify cultures when the real thrust should be on controlling the disease. 


\section{Serology}

Before the current interest in molecular techniques, serodiagnosis opened the possibility of rapid diagnoses directly from infected fish tissues even on the fish farm. Polyclonal antisera were effective at recognising the presence of pathogens when used in the fluorescent antibody test, whole cell agglutination, antibody-coated latex particles (= latex test), the immuno-India ink technique (=Geck test) or the enzyme linked immunosorbent assay (ELISA) (e.g. Saeed and Plumb 1987). The availability of highly specific monoclonal antibodies, such as those marketed by Aquatic Diagnostics Limited (Stirling; Goerlich et al. 1984), reduced the chance of misidentification; with polyclonal antisera there was always the risk of cross-reactions with resultant erroneous conclusions. Techniques include:

(1) Whole cell agglutination using polyclonal antisera has been used extensively for identifying cultures with accuracy depending on the specificity of the antiserum (e.g. Kitao 1982). A culture is mixed with antiserum in the presence of saline on a microscope slide and a positive result indicated by clumping of the bacteria observed within 2 min.

(2) Latex agglutination involved antisera/antibodies that were absorbed onto latex particles. Pure or mixed cultures or pathological material containing pathogens are mixed with the reagent on a glass or plastic surface. A positive reaction as indicated by clumping of the latex particles develops within $2 \mathrm{~min}$. The technique has been demonstrated to be successful for the diagnosis of Hitra disease/cold-water vibriosis (e.g. McCarthy 1975; Sakai et al. 1986). Commercial kits have been developed, e.g. by BioNor in Norway, and used extensively in diagnostic laboratories (Romalde et al. 1995). A variation in the technique involves the use of antibody-sensitised cells of Staphylococcus aureus instead of latex particles, and has been used successfully for the diagnosis of Aeromonas salmonicida and R. salmoninarum (e.g. Kimura and Yoshimizu 1984).

(3) Immuno-india ink technique (= Geck technique) involved the use of india ink and antiserum, which was reacted with the bacterial suspension on a microscope slide. A positive result, which developed within $15 \mathrm{~min}$, was the observation by microscopy of bacterial cells clearly outlined in india ink. Unfortunately, negative results, i.e. unstained bacterial cells, were difficult to visualise. The technique was described for A. salmonicida (McCarthy and Whitehead 1977) and has had only limited use in diagnostics.

(4) The fluorescent antibody technique permitted the observation of bacterial cells directly in tissues (Kawahara and Kusuda 1987). The approach utilised antise- rum, fluorescein isothiocyanate, a suspension of the pathogen or pathological material and a fluorescence microscope. A positive response was the presence of fluorescing cells, which were observed with the fluorescence microscope. However, fluorescence faded after 20-30 min, which necessitated rapid observation.

(5) The enzyme-linked immunosorbent assay (ELISA) was both specific and sensitive, and opened up the possibility of field diagnoses (e.g. Austin et al. 1986). The technique involved antibody-coated plastic or glass surfaces, on which were captured bacterial cells from cultures or pathological material. In sequence, there was addition of an antibody-enzyme conjugate (typically, alkaline phosphatase or horseradish peroxidase) and an enzyme-substrate ( $o$-phenylenediamine for alkaline phosphatase). A positive reaction in terms of a colour change would develop within $60 \mathrm{~min}$. Developments included indirect ELISA, indirect blocking ELISA and competitive ELISA (e.g. Swain and Nayak 2003).

(6) Immunohistochemistry found use for recognising pathogens, e.g. Aliivibrio salmonicida and Photobacterium damselae subsp. piscicida in fresh and fixed tissues (Abu-Elala et al. 2015; Evensen et al. 1991).

(7) A refinement to the ELISA involved polyclonal antibody-coated gold nanoparticles in an immunoassay, which enabled the rapid, sensitive and specific detection of pathogens directly in tissues within $45 \mathrm{~min}$ (Saleh et al. 2011).

To some extent, serological techniques have declined in use since the developments in molecular biology. However, serology is used routinely for the identification of cultures in the laboratory, and some ELISA kits are still on the market. For example, the Central Institute of Freshwater Aquaculture in India developed two agglutination and ELISA kits for use by fish farmers in field conditions.

\section{Culture-independent methods-molecular biology}

Molecular methods with their high sensitivity and specificity have become the favoured options in many laboratories for the diagnosis of fish diseases (e.g. Abu-Elala et al. 2015; Bartkova et al. 2017; Fernandez-Alvarez et al. 2016; Keeling et al. 2013; Mooney et al. 1995; Yan et al. 2018). Techniques capable of detecting virtually single cells have been described. For example, Hiney et al. (1992) reported a polymerase chain reaction (PCR) that was capable of detecting 2 cells of $A$. salmonicida, whereas Høie et al. (1997) detected $10^{3}$ and $10^{4}$ colony forming units (CFUs) of A. salmonicida in $100 \mathrm{ml}$ of kidney suspension with $16 \mathrm{~S}$ rRNA sequencing and plasmid primers, respectively. Subsequent developments included nested PCR (Taylor and Winton 2002), terminal-restriction fragment length polymorphism 
(RFLP) (Nilsson and Strom 2002), PCR-RFLP (Puah et al. 2018), multiplex PCR (Chapela et al. 2018), real-time PCR (Keeling et al. 2013), quantitative real-time-PCR (Du et al. 2017), real-time recombinase polymerase amplification (Pang et al. 2019) and reverse transcription-multiplex PCR (Rattanachaikunsopon and Phumkhachorn 2012). All these techniques reported extremely high levels of sensitivity, detecting numbers of cells well below the level associated with occurrences of clinical disease (Austin and Austin 2016). This raises the issue about the significance of positive results. If overt disease signs have been observed, then positivity with molecular tools provides strong indication of the identity of the pathogen. If clinical signs are absent, then positivity may suggest the presence of asymptomatic or carrier fish or background populations of the pathogen present in the aquatic environment. In short, the data need to be interpreted critically.

The ability to discriminate between two or more pathogens even from different genera was an obvious improvement for diagnosticians. Thus, the triplex loop-mediated isothermal amplification (LAMP) method detected and discriminated $V$. alginolyticus, $V$. anguillarum and $V$. harveyi with a high level of sensitivity from experimentally infected fish (Yu et al. 2013). Similarly, other techniques have mirrored the ability to differentiate between various bacterial pathogens. Thus, González et al. (2004) used a multiplex PCR and DNA microarray for the simultaneous and differential diagnosis of A. salmonicida, Photobacterium damselae subsp. damselae, $V$. anguillarum, V. parahaemolyticus and $V$. vulnificus with a minimum detection limit of the equivalent of four to five bacterial cells. Moreover, Matsuyama et al. (2006) developed a low-density oligonucleotide DNA array for the detection and discrimination of multiple Photobacterium and Vibrio spp. Similarly, DNA microarrays detected Aeromonas hydrophila, Nocardia seriolae, S. iniae, $V$. alginolyticus, V. anguillarum and V. harveyi (Shi et al. 2012); another publication described the detection of $A$. hydrophila, Edwardsiella tarda, Flavobacterium columnare, L. garvieae, Photobacterium damselae, Pseudomonas anguilliseptica, $S$. iniae and $V$. anguillarum with sensitivities of $10^{3} \mathrm{CFU} / \mathrm{ml}$ for pure cultures (Chang et al. 2012). The simultaneous recognition of Photobacterium damselae, Pseudomonas baetica, Tenacibaculum maritimum, $T$. soleae and $V$. harveyi was achieved with reverse line blot hybridisation with the sensitivity ranging from 1 to $100 \mathrm{pg}$ of genomic DNA of the pure culture (López et al. 2012). Another example was the multiple PCR-RNA polymerase that differentiated Photobacterium damselae, V. harveyi and $V$. ichthyoenteri in olive flounder with detection limits in kidney of $2.5 \times 10^{6} \mathrm{CFU} / \mathrm{g}, 2.5 \times 10^{4} \mathrm{CFU} / \mathrm{g}$ and $2.5 \times 10^{5}$ $\mathrm{CFU} / \mathrm{g}$, respectively (Kim et al. 2014). In addition, a realtime fluorogenic LAMP detected $N$. seriolae, Pseudomonas putida, S. iniae, V. alginolyticus, V. anguillarum, V. fluvialis,
$V$. harveyi, V. parahaemolyticus, $V$. rotiferianus and $V$. vulnificus with a reaction time of $<30$ min (Zhou et al. 2014). The question about which method is best largely reflects personal choice. However, all the techniques described to date are noted for their specificity and sensitivity. It is hoped that future developments will enhance the applicability of molecular methods to field use thereby enabling both rapid and accurate diagnoses, which would facilitate the instigation of meaningful disease control strategies.

\section{The issue of possible co-infections}

The possibility that disease may be attributed to two or more different pathogens in the same host either occurring together or sequentially has slowly gained recognition, and complicates diagnostic procedures. Certainly, co-infection may affect the severity of disease as the susceptibility to different pathogens may be changed with mixed infections. Of course, there will be implications for diagnosis and immunoprophylaxis (Kotob et al. 2016). In particular, it has been considered to be highly likely that co-infection may well reduce the beneficial effect of vaccination (Figueroa et al. 2017). Examples of co-infection have reached the scientific literature, and incidences appear to be increasing possibly as scientists become aware of, and actively look for, evidence. Thus, Loch et al. (2012) reported that diseased Chinook salmon (Oncorhynchus tshawytscha), that were returning to spawn in tributaries of Lake Michigan, USA, contained numerous bacterial pathogens. Unfortunately, many of the current approaches to diagnoses would be unlikely to recognise co-infections or cases of microbial succession whereby one organism initiates an infection with others developing and/or exacerbating the condition. The primary reason may be that the presence of more than one organism in diseased animals would be interpreted by many diagnosticians as evidence of contamination. A possible explanation would be that secondary invaders or saprophytes were colonising already diseased tissue. This may have been the case with Aeromonas. hydrophila, which was isolated from fish with columnaris that were recovered from lakes in Saskatchewan, Canada (Scott and Bollinger 2014). Certainly, it is speculative how many cases of co-infections have been missed and not reported. Nevertheless, there are examples of co-infections involving bacteria with other bacteria, or parasites or viruses. Loach (Misgurnus anguillicaudatus), which were farmed in China, harboured a new disease that was associated with two bacterial taxa, namely Shewanella putrefaciens and V. anguillarum (Qin et al. 2014). In addition, Pseudomonas anguilliseptica was found with Delftia acidovorans in European eels (Andree et al. 2013). Moritella viscosa and Aliivibrio wodanis occurred in salmon with winter ulcer disease (Hjerde et al. 2015). It was considered from cell culture evidence involving use of culture supernatants 
that Aliivibrio wodanis secreted toxins and influenced the development of infection by Moritella viscosa (Karlsen et al. 2014).

There are examples of bacteria causing infections in conjunction with parasites. For example, $R$. salmoninarum and Nanophyetus salmincola occurred in wild juvenile Chinook salmon (Sandell et al. 2015). Yersinia ruckeri and Neoparamoeba perurans, the latter of which causes amoebic gill disease, have been reported to co-infect Atlantic salmon in Tasmania, Australia (Valdenegro-Vega et al. 2015). The freshwater trematode Nanophyetus salmincola impaired the immune function of juvenile Chinook salmon, reducing resistance to V. anguillarum (Roon et al. 2015). Experiments revealed that co-infection of Atlantic salmon with Caligus rogercresseyi and Piscirickettsia salmonis led to decreased survival and reduced specific growth rate among vaccinates compared to infection with the bacterial pathogen alone. Moreover, the bacterial loading and clinical signs of disease were significantly increased in co-infected fish (Figueroa et al. 2017).

Examples of infections involving bacteria and viruses include co-infection of Edwardsiella tarda with aquabirnavirus that led to higher mortalities in Japanese flounder (Pakingking et al. 2003). A. salmonicida together with infectious salmon anaemia virus caused secondary infections to infectious pancreatic necrosis virus in Atlantic salmon (Johansen and Sommer 2001). V. harveyi and Edwardsiella tarda co-infected olive flounder with aquatic birnavirus leading to heavy mortalities in Korean farms (Oh et al. 2006).

Diseases may involve bacteria, viruses and parasites. For example, bathing of salmon in Chile to treat $C$. rogercressey $i$ resulted in increased stress and immunosuppression, which in turn led to chronic caligidosis and a higher prevalence of disease caused by $N$. perurans, $P$. salmonis and infectious salmon anaemia virus (Gonzalez et al. 2016).

\section{Conclusions}

For routine diagnostics, it is questionable whether culturedependent approaches will continue in widespread use if the aim is purely to equate a disease with its pathogen. Certainly, reliance on culturing has not always been successful for the recovery of pathogens, due to the lack of or use of suitable media and appropriate incubation conditions. It is argued that with the move away from culturing and phenotyping, diagnostics lost much of the previous subjectivity and inaccuracies caused by reliance on inappropriate diagnostic schema, notably those developed for medically important bacteria. Clearly, molecular techniques have improved the accuracy of bacterial identification, and progressed from use only in specialised laboratories to those involved with routine diagnostics. However, it is prudent to remember that serology currently offers the possibility of rapid, fieldbased diagnoses, as exemplified by ELISA kits. Yet for both molecular and serological systems, there are concerns about positive reactions for what are ultrasensitive methods, especially if overt disease signs are absent. The possibility exists that some positive results may reflect the recognition of natural background populations of pathogens that are not necessarily relevant for disease diagnoses. Also, there are concerns about false positive results, which could elicit economically costly responses. To be effective, diagnoses need to consider all available information including the clinical signs of disease before making firm conclusions. Diagnoses need to help, not hinder the management of fish diseases.

\section{Compliance with ethical standards}

Conflict of interest The author declares that there is no conflict of interest.

Human and animal rights This article does not contain any studies with human participants or animals performed by the author.

\section{References}

Abu-Elala NM, Abd-Elsalam RM, Marzouk MS (2015) Molecular and immunohistochemical diagnosis of Photobacterium damselae subsp. piscicida during naturally occurring disease in Egypt. J World Aquac Soc 46:583-595

Andree KR, Rodgers CJ, Furones D, Gisbert E (2013) Co-Infection with Pseudomonas anguilliseptica and Delftia acidovorans in the European eel, Anguilla anguilla (L.): a case history of an illegally trafficked protected species. J Fish Dis 36:647-656

Austin B (2017) The value of cultures to modern microbiology. Antonie van Leeuwenhoek 110:1247-1256

Austin B, Austin DA (2016) Bacterial fish pathogens, disease of farmed and wild fish, 6th edn. Springer, Dordrecht

Austin B, Bishop I, Gray C, Watt B, Dawes J (1986) Monoclonal antibody-based enzyme-linked immunosorbent assays for the rapid diagnosis of clinical cases of enteric redmouth and furunculosis in fish farms. J Fish Dis 9:469-474

Bartkova S, Kokotovic B, Skall HF, Lorenzen N, Dalsgaard I (2017) Detection and quantification of Aeromonas salmonicida in fish tissue by real-time PCR. J Fish Dis 40:231-241

Behera BK, Bera AK, Paria P, Das A, Parida PK, Kumari S, Bhowmick S, Das BK (2018) Identification and pathogenicity of Plesiomonas shigelloides in silver carp. Aquaculture 493:314-318

Chang CI, Hung PH, Wu CC, Cheng TC, Tsai JM, Lin KJ, Lin CY (2012) Simultaneous detection of multiple fish pathogens using a naked-eye readable DNA microarray. Sensors 12:2710-2728

Chapela M-J, Ferreira M, Ruiz-Cruz A, Martin-Varela I, FernandezCasal J, Garrido-Maestu A (2018) Application of real-time PCR for early diagnosis of diseases caused by Aeromonas salmonicida, Vibrio anguillarum, and Tenacibaculum maritimum in turbot: a field study. J Appl Aquac 30:76-89

Du YS, Liu Y, Xiao P, Meng LJ, Liu PF (2017) Development and application of a quantitative real-time polymerase chain reaction assay for the detection of Aeromonas salmonicida. J World Aquac Soc 48:574-582 
Eissa IAM, Abou-Elgheit SN, Dessuki AA, Hassanin AAI, Mostafa LT (2019) Advanced diagnosis of vibriosis among some marine fishes in Lake Temsah, Egypt. J Hellenic Vet Med Soc 70:1339-1346

Evensen Ø, Espelid S, Håstein T (1991) Immunohistochemical identification of Vibrio salmonicida in stored tissues of Atlantic salmon Salmo salar from the first known outbreaks of coldwater vibriosis ('Hitra disease'). Dis Aquat Org 10:185-189

Fernandez-Alvarez C, Gonzalez SF, Santos Y (2016) Development of a SYBR green I real-time PCR assay for specific identification of the fish pathogen Aeromonas salmonicida subsp. salmonicida. Appl Microbiol Biotechnol 100:10585-10595

Figueroa C, Bustos P, Torrealba D, Dixon B, Soto C, Conejeros P, Gallardo JA (2017) Coinfection takes its toll: sea lice override the protective effects of vaccination against a bacterial pathogen in Atlantic salmon. Sci Rep 7:17817

Goerlich R, Schlüsener HJ, Lehmann J, Greuel E (1984) The application of monoclonal antibodies to diagnosis of Aeromonas salmonicida infections in fishes. Bull Eur Assoc Fish Pathol 4:66

Gonzalez L, Robles C, San Martin MC (2016) Management issues regarding caligidosis treatment on salmon farms in Chile affected by infection salmon anaemia virus (ISAV), Piscirickettsia salmonis and Neoparamoeba perurans. Ocean Coast Manag 123:74-83

González SF, Krug MJ, Nielsen ME, Santos Y, Call DR (2004) Simultaneous detection of marine fish pathogens by using multiplex PCR and a DNA microarray. J Clin Microbiol 42:1414-1419

Hiney M, Dawson MT, Heery DM, Smith PR, Gannon F, Powell R (1992) DNA probe for Aeromonas salmonicida. Appl Environ Microbiol 58:1039-1042

Hjerde E, Karlsen C, Sørum H, Parkhill J, Willassen NP, Thomson NR (2015) Co-cultivation and transcriptome sequencing of two coexisting fish pathogens Moritella viscosa and Aliivibrio wodanis. BMC Genom 16:447

Høie S, Heum M, Thoresen OF (1997) Evaluation of a polymerase chain reaction-based assay for the detection of Aeromonas salmonicida ss. salmonicida in Atlantic salmon Salmo salar. Dis Aquat Org 30:27-35

Johansen LH, Sommer AI (2001) Infectious pancreatic necrosis virus infection in Atlantic salmon Salmo salar post-smolts affects the outcome of secondary infections with infectious salmon anaemia virus or Vibrio salmonicida. Dis Aquat Org 47:109-117

Karlsen C, Vanberg C, Mikkelsen H, Sørum H (2014) Co-infection of Atlantic salmon (Salmo salar), by Moritella viscosa and Aliivibrio wodanis, development of disease and host colonization. Vet Microbiol 171:112-121

Kawahara E, Kusuda R (1987) Direct fluorescent antibody technique for diagnosis of bacterial disease in eel. Nippon Suisan Gakkaishi 53:395-399

Keeling SE, Brosnahan CL, Johnston C, Wallis R, Gudkovs N, McDonald WL (2013) Development and validation of a real-time PCR assay for the detection of Aeromonas salmonicida. J Fish Dis 36:495-503

Kim MS, Cho JY, Choi HS (2014) Identification of Vibrio harveyi, Vibrio ichthyoenteri, and Photobacterium damselae isolated from olive flounder Paralichthys olivaceus in Korea by multiplex PCR developed using the rpoB gene. Fish Sci 80:333-339

Kimura T, Yoshimizu M (1984) Coagglutination test with antibodysensitized staphylococci for rapid serological identification of rough strains of Aeromonas salmonicida. Bull Jpn Soc Sci Fish 50:439-442

Kitao T (1982) The methods for detection of Streptococcus sp. causative bacteria of streptococcal disease of cultured yellowtail (Seriola quinqueradiata). Fish Pathol 17:17-26

Kotob MH, Menanteau-Ledouble S, Kumar G, Abdelzaher M, El-Matbouli M (2016) The impact of co-infections on fish: a review. Vet Res 47:98
Loch TP, Scribner K, Tempelman R, Whelan G, Faisal M (2012) Bacterial infection of Chinook salmon, Oncorhynchus tshawytscha (Walbaum) returning to gamete collecting weirs in Michigan. J Fish Dis 35:39-50

López JR, Navas JI, Thanantong N, de la Herran R, Sparagano OAE (2012) Simultaneous identification of five marine fish pathogens belonging to the genera Tenacibaculum, Vibrio, Photobacterium and Pseudomonas by reverse line blot hybridization. Aquaculture 324:33-38

Matsuyama T, Kamaishi T, Oseko N (2006) Rapid discrimination of fish pathogenic Vibrio and Photobacterium species by oligonucleotide DNA array. Fish Pathol 41:105-112

McCarthy DH (1975) Detection of Aeromonas salmonicida antigen in diseased fish tissue. J Gen Microbiol 88:384-386

McCarthy DH, Whitehead P (1977) An immuno-India ink technique for rapid laboratory diagnosis of fish furunculosis. J Appl Bacteriol 42:429-431

Mooney J, Powell E, Clabby C, Powell R (1995) Detection of Aeromonas salmonicida in wild Atlantic salmon using a specific DNA probe test. Dis Aquat Org 21:131-135

Nilsson WB, Strom MS (2002) Detection and identification of bacterial pathogens of fish in kidney tissue using terminal restriction fragment length polymorphism (T-RFLP) analysis of 16S rRNA genes. Dis Aquat Org 48:175-185

Oh MJ, Kim WS, Kitamura SI, Lee HK, Son BW, Jung TS, Jung SJ (2006) Change of pathogenicity in olive flounder Paralichthys olivaceus by co-infection of Vibrio harveyi, Edwardsiella tarda and marine birnavirus. Aquaculture 257:156-160

Pakingking R, Takano R, Nishizawa T, Mori K-I, Iida Y, Arimoto M, Muroga K (2003) Experimental coinfection with aquabirnavirus and viral hemorrhagic septicemia virus (VHSV), Edwardsiella tarda or Streptococcus iniae in Japanese flounder Paralichthys olivaceus. Fish Pathol 38:15-21

Pang J-H, Wang Q, Fei Y-J, Zhua P, Qiao L-L, Huang H-L, Dang C-Y, Gao W-F (2019) A real-time recombinase polymerase amplification assay for the rapid detection of Vibrio harveyi. Mol Cell Probes 44:8-13

Puah SM, Khor WC, Kee BP, Tan JAMA, Puthucheary SD, Chua KH (2018) Development of a species-specific PCR-RFLP targeting rpoD gene fragment for discrimination of Aeromonas species. J Med Microbiol 67:1271-1278

Qin L, Zhu M, Xu J (2014) First report of Shewanella sp. and Listonella sp. infection in freshwater cultured loach, Misgurnus anguillicaudatus. Aquac Res 45:602-608

Rattanachaikunsopon P, Phumkhachorn P (2012) Detection of Aeromonas salmonicida by reverse transcription-multiplex polymerase chain reaction. Biosci Biotechnol Biochem 76:665-670

Romalde JL, Magariños B, Fouz B, Bandín I, Núñez S, Toranzo AE (1995) Evaluation of BIONOR Mono-kits for rapid detection of bacterial fish pathogens. Dis Aquat Org 21:25-34

Roon SR, Alexander JD, Jacobson KC, Bartholomew JL (2015) Effect of Nanophyetus salmincola and bacterial co-infection on mortality of juvenile chinook salmon. J Aquat Anim Health 27:209-216

Saeed MO, Plumb JA (1987) Serological detection of Edwardsiella ictaluri Hawke lipopolysaccharide antibody in serum of channel catfish Ictalurus punctatus Rafinesque. Dis Aquat Org 10:205-209

Sakai M, Atsuta S, Kobayashi M (1986) A streptococcal disease of cultured Jacopever, Sebastes schlegeli. Suisanzoshuku (Aquic) 34:171-177

Saleh M, Soliman H, Haenen O, El-Matbouli M (2011) Antibodycoated gold nanoparticles immunoassay for direct detection of Aeromonas salmonicida in fish tissues. Dis Aquat Org 34:845-852

Sandell TA, Teel DJ, Fisher J, Beckman B, Jacobson KC (2015) Infections by Renibacterium salmoninarum and Nanophyetus salmincola Chaplin are associated with reduced growth of juvenile 
Chinook salmon, Oncorhynchus tshawytscha (Walbaum), in the Northeast Pacific Ocean. J Fish Dis 38:365-378

Scott SJ, Bollinger TK (2014) Flavobacterium columnare: an important contributing factor to fish die-offs in southern lakes of Saskatchewan, Canada. J Vet Diagn Invest 26:832-836

Shi YH, Chen J, Li CH, Lu XJ, Zhang DM, Li HY, Zhao ZX, Li MY (2012) Detection of bacterial pathogens in aquaculture samples by DNA microarray analysis. Aquaculture 338-341:29-35

Swain P, Nayak SK (2003) Comparative sensitivity of different serological tests for seromonitoring and surveillance of Edwardsiella tarda infection of Indian major carps. Fish Shellfish Immunol 15:333-340

Taylor PW, Winton JR (2002) Optimization of nested polymerase chain reaction assay for identification of Aeromonas salmonicida, Yersinia ruckeri, and Flavobacterium psychrophilum. J Aquat Anim Health 14:216-224

Valdenegro-Vega VA, Cook M, Crosbie P, Bridle AR, Nowak BF (2015) Vaccination with recombinant protein ( $\mathrm{r} 22 \mathrm{C03})$, a putative attachment factor of Neoparamoeba perurans, against AGD in Atlantic salmon (Salmo salar) and implications of a co-infection with Yersinia ruckeri. Fish Shellfish Immunol 44:592-602

Verner-Jeffreys DW, Roberts E, Driscoll J, Bayley AE, Algoët M (2011) Evaluation of the Biolog Microlog 1 system for the identification of gram positive cocci pathogenic for fish. Bull Eur Assoc Fish Pathol 31:171-181

Yan WL, Gu LD, Liu S, Ren W, Lyu MS, Wang SJ (2018) Identification of a highly specific DNA aptamer for Vibrio vulnificus using systematic evolution of ligands by exponential enrichment coupled with asymmetric PCR. J Fish Dis 41:1821-1829

Yang R, Liu Y, Wang Y, Lei MK, Pan GY, Wen JF, Gong Q, Ren L, Huang J, Wen XT, Cao SJ, Huang Y, Huang XB, Ma XP, Han XF, Zhao Q, Wen YP, Wu R, Lin JC, Yan QG (2018) Pathogenesis and pathological analysis of Edwardsiella tarda from Dabry's sturgeon (Acipenser dabryanus) in China. Aquaculture 495:637-642

Yu LP, Hu YH, Zhang XH, Sun BG (2013) Development of a triplex loop-mediated isothermal amplification method for rapid on-site detection of three Vibrio species associated with fish diseases. Aquaculture 414:267-273

Zhou QJ, Wang L, Chen J, Wang RN, Shi YH, Li CH, Zhang DM, Yan XJ, Zhang YJ (2014) Development and evaluation of a realtime loop-mediated isothermal amplification assay integrated on a microfluidic disc chip (on-chip LAMP) for rapid and simultaneous detection of ten pathogenic bacteria in aquatic animals. J Microbiol Methods 104:26-35 